\title{
Spatial Distribution of Air Quality Parameters Using Geographic Information System (GIS) of Aurangabad City
}

\author{
Mr. Onkar K. Jogdand \& Dr. N.N.Bandela \\ Department of Environmental Science, \\ Dr. Babasaheb Ambedkar Marathwada University, Aurangabad, \\ Maharashtra (INDIA) -431004. \\ Email:onkar.jogdand@gmail.com
}

\begin{abstract}
Air contamination is one of the greatest significant environmental matters throughout the country state. The aim of the study is to collect, store and retrieve the data for spatial analysis using GIS technique, here we applied the interpolation technique for preparation of spatial distribution map with respect to air quality parameters such as SOx, NOx and RSPM. The lesson reveals that distributions of air contaminant are moderate in the areas of S. B. College, Collector office and CADA Office was identified. It is due to the over the traffic of vehicles and other urban activities. Identified air pollutant RSPM is causing the various types of respiratory diseases to human beings in the study area. Air contamination has to turn into a topic of undecorated suffering, chiefly in mega-cities and municipal areas. Air quality observing is essential in metropolitan and trade areas for careful research to make easy for the future of industrial development. Air quality assessment review has been sanctioned in areas of Aurangabad for three important parameters for a predetermined period and compared with standards. The geostatic representing technique consumes went approved away with interpolation method to predict the pollution level in between sampling stations with spatial maps using Arc GIS software.
\end{abstract}

Key words: Air Pollution, Spatial Interpolation, Geographic Information System (GIS), air quality, $\mathrm{SO}_{x}, \mathrm{NO}_{\mathrm{x}}$ and RSPM etc.

\section{INTRODUCTION}

The World Health Organization (WHO) guesses that approximately $90 \%$ of the citizens wide-reaching breathe polluted air. Air contamination is the release of chemicals, particulate matter, or the organic resources that origin destruction to humans and also reimbursement the natural surroundings into the environment. The air contamination is one of major threats of recent decades, which has a strict toxicological contact on anthropological condition and the atmosphere. The production sources of motor vehicles and mechanized processes add the major part of air pollution. The geographic information system is a software tool to normal, explore manage and present all kinds of spatial or environmental data which expert estimation of the GIS user or analyst, produces a solution to spatial problems. (Kankariya, R.S. et al., 2015). According to the Bureau of Indian Standards (BIS), air contamination refers "the occasion in ambient atmosphere of the substances, commonly substantial from the action of person being, in sufficient concentration, present-day for a sufficient time and under situation such as to interfere with relieve health or welfare of a person or with functional use or satisfaction of the property" (Gunasekaran, et al., 2011). Now this revision, the
GIS spatial investigations were used to identify air pollution levels. Air pollution is a leading problem in an urban areas and nascent countries. It origins respirational sicknesses and an insistent complaint (McCubbin and Delucchi, 1999) then special effects on soil (EI Desouky et al., 1998) in addition to plantation (Zhang et al., 2000). Individually the anthropoid activities besides the usual ecofriendly processes are one of the causes of pollution. The periodic variations (Cheng and Lam, 1997) and the biological responses contribute to the absorption of impurities in the air. Aerial vapors and constituent part remained not ever forecast as a threat to the ecological balance till the precious fluctuations in their absorptions through the commencement of an industrial area. An anthropogenic discharge from the numerous industrial, native and vehicle sources have increased to an assorted then ultimately have led to many worldwide problems. Approximately 300 different air contaminants have been identified, which are greatest organic and fire sources. The appropriate class sampling at all specific position can be a matter, consequently, it is very considerable to obligate a suitable process to estimate or predict the numbers for the area under study. 


\section{International Journal of Research in Advent Technology, Vol.7, No.5, May 2019 E-ISSN: 2321-9637 \\ Available online at www.ijrat.org}

\section{STUDY AREA}

The Aurangabad town is located $19^{\mathrm{O}} 52$ ' 33.67" N, $75^{\circ} 20^{\prime} 35.84^{\prime \prime} \mathrm{E}$ in the northern portion of the state of Maharashtra and situated at western section of India. The city of Aurangabad is away about $403 \mathrm{Km}$ from state Mumbai and located on the banks of the Kham River. The Aurangabad is a capital of Marathwada region, where the industrial development of Aurangabad is more into the Asian region. It is due to the over traffic of vehicles, other urban activities and it is an Education Hub; so for that population has rapidly growing due to that, air quality get deteriorated. The significance of Aurangabad is great,

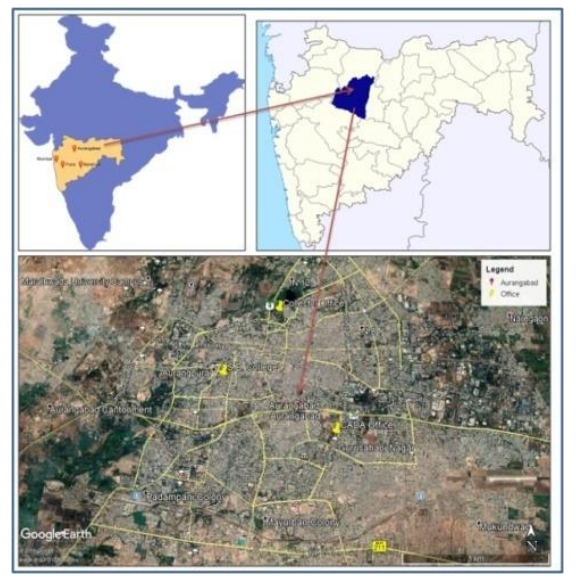

Fig.1. Location Map of Study Area

\section{METHODOLOGY}

The collection of primary and secondary data throughout the research works by the High Volume Air Sampler (Envirotech APM 460BL) subsequently the particulars of sampling methods and analyses of some selected air pollutants monitored by national ambient air quality standard (NAAQS). Digital Elevation Model (DEM) has been recycled as an active tool for traveling the spatial and temporal variance of air pollutants in environment. High Volume Air Sampler is run in the exposed air for 24 hours and initial and final flow rate values are recorded. The primary data is associated with secondary data i.e. baseline data of MPCB were collected for the analysis of Air Quality Parameters.

\section{SOFTWARE USED:}

ArcGIS 10.2.2 software was used for the preparation of spatio-temporal distribution chart. The Maps are used to represent the spatial difference in the concentration of air pollutants available in ambient air. A Kriging technique was used for spatial interpolation of Spatial Data analysis. outstanding to its nearness to world inheritance sites of Ajanta and Ellora.An atmosphere of Aurangabad city is sensible through temperate wintertime in the months of November-February besides warm summers from April to June. The warm weather is hot and winters are cold. It is fine again to come here between October and March. The Aurangabad town is situated in the Maharashtra state of India. As per provisional reports of Survey India, a resident of Aurangabad in 2011 is $1,175,116$; of which male and female are 609,206 and 565,910 respectively. The standard annual rainfall of the city is $710 \mathrm{~mm}$.

\section{THEMATIC MAPS:}

The spatial distribution map establishment systems can be like simpler, sometimes making a map besides doing investigation involving too complex models that mimic the real world by linking data layers. Specific context for choosing parameters that might be required during the analysis. Spatial Data analysis is carried out with the help of GIS (Geographical Information System) software. The Geographic features are either discrete, continuous phenomena or summarized by area. In order to prepare the thematic maps required the Survey of India toposheet no. 47M/5 (scale-1:50,000) covering the study area were obtained and used. Temporal variation in air quality was prepared and the secondary data for these three locations were collected from the Maharashtra Pollution Control Board (MPCB), Aurangabad for the period of 2013 to 2017 for comparative analysis. FIG.1. LOCATION

\section{INVERSE DISTANCED WEIGHT (IDW):}

Design for calculating the values of sample fewer locations precisely, Inverse Distance Weighing technique allocates a higher weight towards the close by points than the remote away ones. Accordingly the method (IDW) needs to be a systematically filled linkage of uniformly spaced interpretations. This method essentially reviews a weighted moving normal. A linear determination of exposure or remoteness among the sets of arguments and the investigated points is used to analyze the weights. This method initially requires the degree of the area to be assimilated and which selects the pilot opinion in the procedure. In general ordinary of tasted points in the nearby cells is recycled to calculate the unidentified cell values. Both time contemporary is a small amount known assessed points, IDW is chosen over Kriging.

Consequently for the spatial modeling of air quality wherever we taken less known samples then determined to choose IDW. 
5. RESULT \& DISCUSSION:

Table 1. The concentration of Air pollution in the study area:

\begin{tabular}{|l|c|c|c|c|c|c|}
\hline \multirow{2}{*}{ Locations } & \multicolumn{2}{|c|}{ SOx } & \multicolumn{2}{c|}{ NOx } & \multicolumn{2}{|c|}{ RSPM } \\
\cline { 2 - 7 } & 2013 & 2017 & 2013 & 2017 & 2013 & 2017 \\
\hline $\begin{array}{l}\text { SB } \\
\text { College }\end{array}$ & 11.53 & 11.61 & 38.96 & 35.40 & 100.74 & 88.53 \\
\hline $\begin{array}{l}\text { Collector } \\
\text { Office }\end{array}$ & 9.01 & 9.54 & 35.14 & 31.44 & 80.83 & 82.83 \\
\hline $\begin{array}{l}\text { CADA } \\
\text { Office }\end{array}$ & 10.11 & 10.40 & 36.73 & 33.95 & 70.02 & 83.88 \\
\hline
\end{tabular}

\section{SPATIALDISTRIBUTION OF SULPHUR} OXIDE (SOX):

The spatial distribution of Sulphur oxide (SOx) concentration is shows in figure no.2 and 3 . The highest value is $11.53 \mu \mathrm{g} / \mathrm{m}^{3}$ in 2013 and while $11.61 \mu \mathrm{g} / \mathrm{m}^{3}$ in the year 2017 recorded at S.B. College and the moderate value of SOx concentration is 10.11

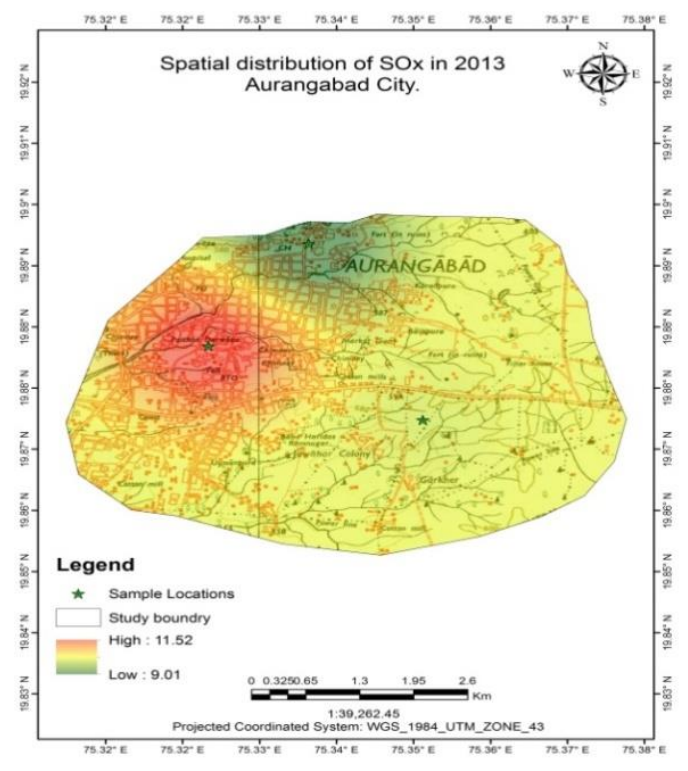

Fig.2 Spatial distribution of SOx in 2013

\section{SPATIALDISTRIBUTION OF NITROUS OXIDE (NOX):}

The spatial distribution of Nitrogen oxide (NOx) concentration is shows in figure no.4 and 5. The highest concentration values of Nitrogen oxide (NOx) were $38.96 \mu \mathrm{g} / \mathrm{m} 3$ in the year 2013 and 35.40 $\mu \mathrm{g} / \mathrm{m}^{3}$ in the year 2017 respectively recorded at S.B. College. The moderate values of NOx concentration $\mu \mathrm{g} / \mathrm{m}^{3}$ in 2013 while $10.40 \mu \mathrm{g} / \mathrm{m}^{3}$ recorded in 2017 at CADA office and the lowermost value is 9.01 $\mu \mathrm{g} / \mathrm{m}^{3}$ of SOx concentration in 2013 and $9.54 \mu \mathrm{g} / \mathrm{m}^{3}$ in 2017 recorded at collector office. All the collected data are analyzed by using interpolation method and spatial distribution maps of air quality maps were prepared.

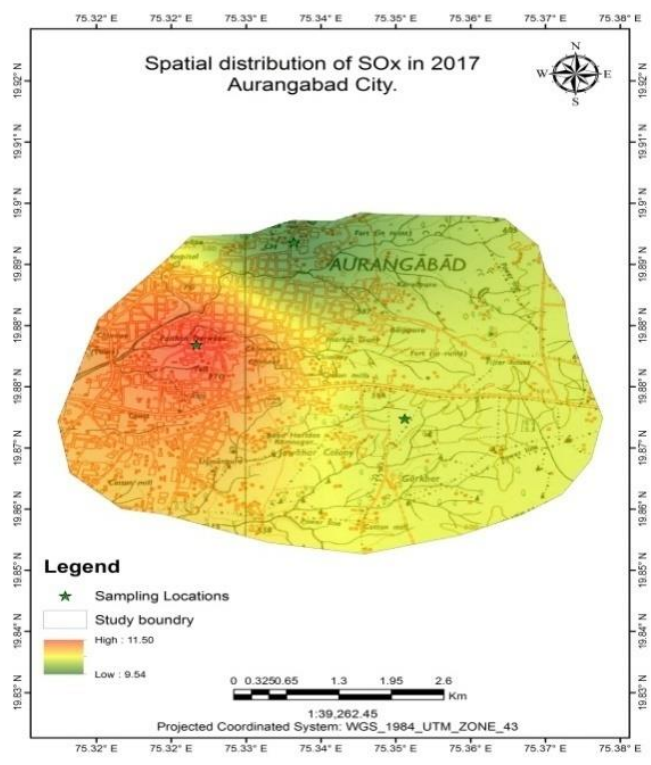

Fig.3 Spatial distribution of SOx in 2017

were $36.73 \mu \mathrm{g} / \mathrm{m}^{3}$ in 2013 while $33.95 \mu \mathrm{g} / \mathrm{m}^{3}$ in 2017 at CADA office. While highest values of NOx concentration in 2013 and $31.44 \mu \mathrm{g} / \mathrm{m}^{3}$ were recorded in the year 2017 at collector office. All the collected data are analyzed by using interpolation method and spatial distribution maps of air quality maps were prepared. 


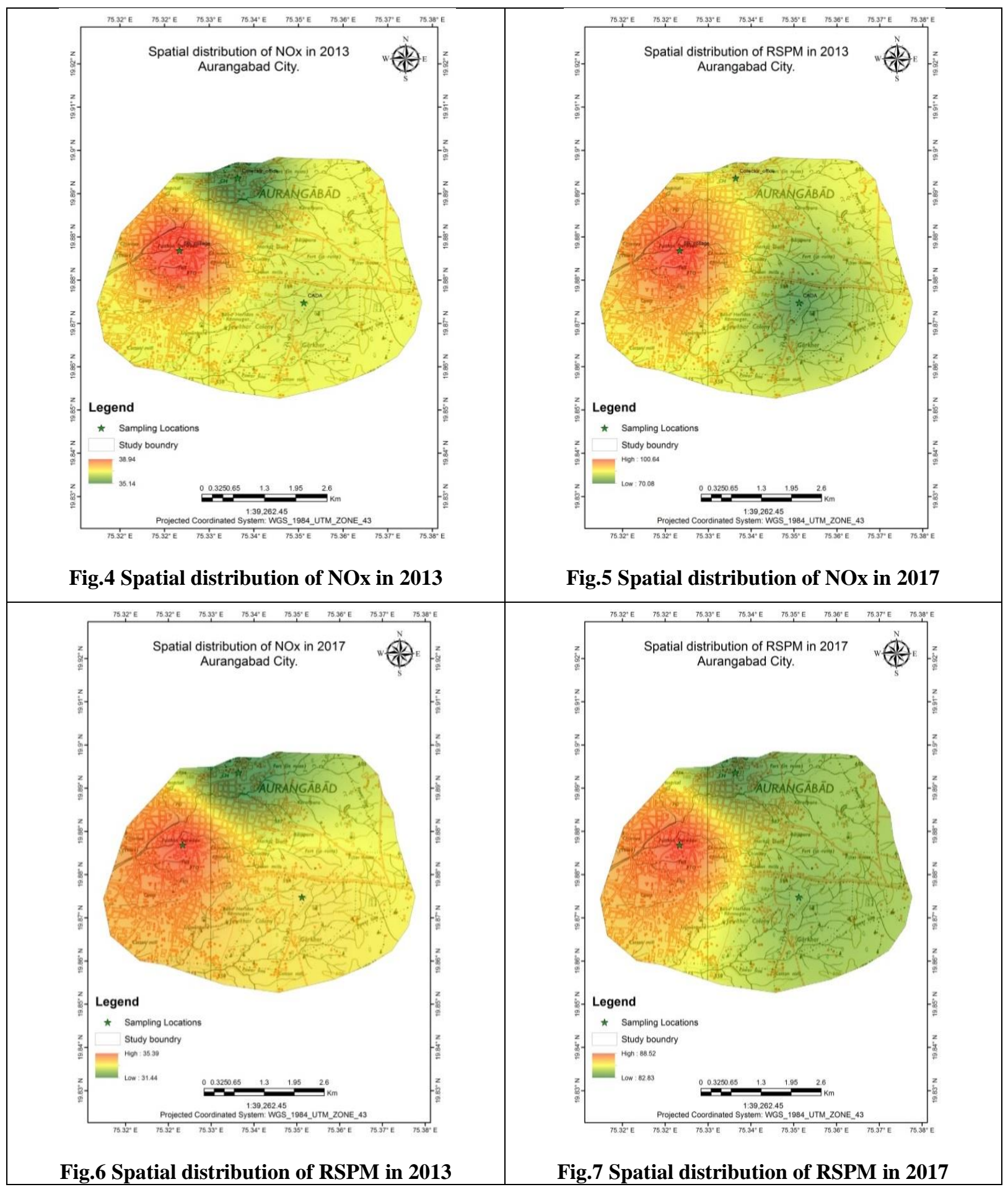

\section{Spatial distribution of RSPM (PM10):}

In this research the concentration of particulate matter (PM10) was recorded maximum value i.e.100.74 $\mu \mathrm{g} / \mathrm{m}^{3}$ at $\mathrm{S}$. B. College area. The minimum concentration value i.e. $70.02 \mu \mathrm{g} / \mathrm{m}^{3}$, of PM 10 was identified along with roadside, that will recorded high levels due to high level emission from the vehicles.
On behalf of the desired investigation ground truth data were collected. The quantity of RSPM samples was randomly selected for the interpolation analysis to produce the air quality maps through using interpolation technique i.e. Inverse Distanced Weight (IDW) method. The outcome of a spatial distribution 


\section{International Journal of Research in Advent Technology, Vol.7, No.5, May 2019 E-ISSN: 2321-9637 \\ Available online at www.ijrat.org}

of RSPM of the study area is presented in the figure no. 6 and figure no.7.

\section{CONCLUSION}

The Ambient air quality details for $\mathrm{SO}_{x}, \mathrm{NO}_{x}$ and RSPM have been collected of Aurangabad city for the period of 2013-2017. The spatial distribution of the ambient air quality has been deliberate through Arc GIS 10.2.2. It was observed that the normal values of air pollutants were beyond the NAAQ standards in the area of S. B. College and the average values are the above NAAQ standards. Hence, they stand as highly polluted areas. All the monitoring locations are coming under commercial zones and residential zones having more vehicular emissions and traffic zones. The study includes that vehicular pollution has a significant impact on ambient air pollution which affects human health. The ambient air quality in Aurangabad city is alarming level and suitable for remedies should be taken before the condition get worse. The air impurities have an effect on human health. Respirable suspended particulate matter (RSPM) abandoned in the respirational territory and caused fitness issues in human. In control of air pollution various measures and an integrated approach are very much imperative to reduce air pollution to the minimal. Additional of ancient vehicles reformulating diesel fuel engine, an overview of liquefied petroleum gas (LPG) and compressed natural gas (CNG), massive enhancements in the substructure and necessary traffic management measures.

\section{REFERENCES:}

[1] Begum B, Biswas S, Hopke P (2006) Temporal variations and spatial distribution of ambient PM 2.5 and PM concentrations in Dhaka, Bangladesh. Sci. Total Environ 358: 36-45. Omar NYMJ, Abas MRB.

[2] Chan C, Yao X (2008) Air pollution in mega cities in China. Atmospheric Environment 42: 142. 12.

[3] Chu, D.A., Kaufman, Y.J., Zibordi, G., Chern, J.D., Mao, J., Li, C. and Holben, B.N. (2003) Worldwide checking of air contamination ended land from EOS-Terra MODIS. J.Geophys. Res. 108 (D21), 4661, doi: 10.1029.

[4] Colbeck I, Nasir ZA, Ali Z (2010) the state of ambient air quality in Pakistan-a review. Environ Sci. Pollut. Res 17: 49-63. 9.

[5] Gurjara BR, Butlerb TM, Lawrenceb MG, Lelieveldb J (2008) Evaluation of emissions and air quality in megacities. Atmospheric Environment 42: 15931606.
[6] Gunasekaran, R.K, Kumarswamy, P.P, Chandrasekaran and Elanchezhian, $\mathrm{R}$. (2012)Monitoring of ambient air quality in Salem University,Tamilnadu ,International Journal of Current Research, Vol.4, Issue, 03,pp.275-280.

[7] Hopkea PK, Cohenb DD, Begumc BA, Biswas SK, Nid B, et al. (2008) urban air quality in the Asian region. Science of the Total Environment 404: 103-112. 3.

[8] Iqbal, M.F. and I.A.Khan. (2014) "Spatiotemporal land Use / Land Cover deviation Investigation and destruction risk plotting of Azad Jammu and Kashmir, Pakistan." An Egyptian Journal of Remote Sensing and Universe Sciences, 17:209-229.

[9] Jain S, Khare M (2008) urban air quality in mega cities: A case study of Delhi City using vulnerability analysis. Environmental Monitoring Assessment 136: 257-265. 11.

[10] Kankariya, R.S.etal. (2015)(GIS Application for Spatial and Temporal Analysis of the air impurities in urban area).International Journal of Advanced Remote Sensing and GIS 2015, Volume 4, Issue 1 ,pp.1120-1129, Article ID Tech -421 ISSN 2320.

[11] Malaysia (API). Engel-Cox, J.A., Holloman, C.H., Coutant, B.W. and Hoff, R.M. (2004) Qualitative and quantifiable assessment of MODIS satellite instrument data for national and metropolitan scale air quality. Atmos. Environ. 38 (16): 2495- 2509.

[12] Matejiceka L, Engst P, Jaňour Z (2006) A GISbased approach to spatiotemporal analysis of environmental pollution in urban areas: A case study of Prague's environment extended by LIDAR data. Ecological Modeling 199: 261277. 18.

[13] Morra P, Bagli S, Spadoni G (2005) The analysis of human health risk with a detailed procedure operating in a GIS environment. Environ Int. 32: 444-454. 22.

[14] Oanh K, Upadhyay N, Zhuang Y, Hao Z, Murthy D, et al. (2006) Particulate air pollution in six Asian cities: Spatial and temporal distributions, and associated sources. Atmospheric Environment 40: 3367-3380. 10.

[15] Scorer, R. S. (1998) Modeling of air pollution- its use and limitations, Clean Air, 28(3): 102- 104.

[16] 16. Shakeel M, Arshad Q, Saeed R, Ahmed T, Khan HMT, et al. (2015) Application of GIS in 
International Journal of Research in Advent Technology, Vol.7, No.5, May 2019

E-ISSN: 2321-9637

Available online at www.ijrat.org

Visualization and Assessment of Ambient Air

Quality ,Sheikhupura City, Pakistan. J.Geogr Nat Disast ISSN: 2167-0587 1000150 Volume 5 • Issue 31000150.

[17] WHO (2012) Most Polluted Countries in Asia. Konrad-Adenauer-Stiftung Media Programme Asia World Health Organization. 13. TPU (2013). 